HEIKKI HEIKKILÄ

\title{
Julkisuus politiikan paikkana
}

Suomen jäsennys Euroopan yhteisössä on noussut syystäkin 90-luvun tärkeimmäksi poliittiseksi kysymykseksi. Asian kiistämättömän merkittäryyden lisäksi jäsenyyskysymystä leimaa kaksinkertainen epävarmuus. Kukaan ei osaa varmasti kertoa, mitä ratkaisu tuo tullessaan. Kukaan ei osaa myöskään tyhjentävästi selittää, mistä kaikista asioista ollaan päättämässä. EY-ratkaisun ongelmallisuus koskee siis paitsi tulevaisuuden avoimuutta, myös päätöksen kattaman alueen määrittelyä. Kysymys onkin lopulta siitä, kuinka tehdä päätöksiä asiasta, jonka rajauksesta ja toimintavaihtcehtojen seurauksista vallitsee avoin epätietoisuus.

Epävarmuus on sotkenut pahasti politiikan tekemisen perinteistä tapaa. Perinpohjaisen selvittelyn ja harkinnan sijasta asia tuotiin keskentekoisena julkisuuteen. Maan johtavat politikot lähtivät kysymään kansalaisten mielipiteitä ennen kuin olivat muodostaneet edes omia kantojaan. Tämä vähintäänkin poikkeuksellinen menettely on johtanut siihen, että EY-kysymyksessä asioiden hoitaminen ja julkisuus ovat kietoutuneet erottamattomasti yhteen. Uudessa tilanteessa on vaikeuksia erottaa, mihin politiikka loppuu ja mistä julkisuus alkaa - ja päinvastoin.

Mikäli poliitikan ja julkisuuden yhteenkietoutuminen on tarkoituksellista ja pysyvää, EY-kysymys voi muuttaa muutakin kuin Suomen ulkopolitiikan, maanviljelijöiden elämän ja vientiteollisuuden asemat. Se merkitsisi politikan tekemisen tavan muutosta, joka tuottaisi ongelmia niin poliitikoille kuin yhteiskuntatieteilijöillekin. Se pakottaisi politiikan ja julkisuuden välisen suhteen arkkimäärittelyjen uudelleen arviointeihin. Kärjistetysti voidaan nimittäin väittää, että poliitikot ja politiikan tutkijat ovat perinteisesti pyrkineet yleensä mitätöimään julkisuuden roolin politiikassa, tiedotustutkijat ja toimittajat ovat taas vastaavasti pyrkineet korottamaan julkisuuden politiikan yläpuolelle.

Politiikan ja julkisuuden yhteenkietoutuminen voidaan nähdä politiikan näkökulmasta positiivisena ilmiönä. Julkisuudessa tapahtuvassa merkitysten luonnissa politiikka voi toteuttaa kahta tehtävää: ensiksikin se hallitsee EY-kysymyksen tapaisten monimutkaisten kysymysten synnyttämän kaksinkertaisen avoimuuden kiteytyä 'vapaasti' toimintavaihtoehdoiksi, toiseksi se kiinnittää ihmisten mielenkiinnon heidän 'yhteisiin asioihinsa' ja sitoo heitä päättämään niistä.

Julkisuus ymmärrettynä politiikan paikaksi edistäisi näin ollen yhteiskunnan kykyä hallita kompleksisuutta, ihmisten osallistumista 'yhteisten asioiden' hoitoon ja tätä kautta ratkaisujen legitimiteettiä. Politiikan ja julkisuuden yhteen kietoutuminen voidaan nähdä jopa mahdollisuutena siirtyä weberiläisestä rutiinien hallitsemasta rationaalisuuden rautahäkistä 'moderniin tilanteeseen'. Modernilla tilanteella tarkoite- 
taan Kyösti Pekosen mukaan uutta kommunikatiivista tilannetta, jossa poliittisesti aktiivinen kansalainen haastetaan hoitamaan 'yhteisiä asioita' (Pekonen 1991, 110-111).

\section{Politiikan ja julkisuuden suhteen määrittelykilpa}

Politiikka on perinteisesti osoittanut julkisuudelle paikan politiikan ulkopuolelta. Sieltä käsin sen tehtäväksi on annettu todellisuuden heijastaminen sellaisena kuin se esiintyy ja millaisena myös politiikka sen näkee. Julkisuuden funktiona on siis politiikan mielestä objektiivisen joukkotiedotuksen konseption mukaisesti "informoida kansalaisyhteiskunnan jäseniä todellisuuden nopeasti muuttuvista osista" (Hemánus \& Tervonen 1986, 215). Koska politiikka kuuluu informoinnin kohteena oleviin todellisuuden osiin, julkisuus katsoo sitä ulkoa päin siitäkin huolimatta, että se itsekin on osa todellisuutta.

Silloin kun julkisuuden vaikutus politiikkaan on tunnustettu, sen on katsottu pinnallistavan politiikkaa ja sotkevan 'asioiden hoitamista asioina'. Näin ollen se on pahimmillaan mädättänyt politiikkaa ja tehnyt siitä tiedotusvälineiden teatteria. Politiikan 'tekemisessä' julkisuuden roolin kasvuun on reagoitu lähinnä harmistuneesti. Politilikan tutkimuksessa taas on rohkaistu poliitikkoja olemaan välittämättä liikaa pinnallisista toimittajista, koska julkisuudella ei ole kuitenkaan ratkaisevaa roolia asioiden hoitamisessa (esim. Wiberg 1989, 51-52).

Poliitikkojen harmistumista kuvaavat esimerkiksi Sdp:n entisen puheenjohtajan Pertti Paasion ohjeet seuraajalleen Ulf Sundqvistille ja entisen pääministerin Harri Holkerin tilannearvio tappiollisten eduskuntavaalien jälkeen (Uusi Suomi 29.4.1991). Paasio toivoi kitkerissä evästyssanoissaan Sundqvistin kommentoivan kaikkea mahdollista kaikissa mahdollisissa käänteissä välittämättä liikaa puheiden sisällöstä. Holkeri taas näki sinipunahallituksen vaalitappion johtuneen sen 'suoraselkäisyydestä' julkisuuden edessä. Holkerin mielestä hallitus ei ollut alistunut markkinoimaan hyviä tekojaan vaan tyytynyt siihen, että julkisuus kertoisi niistä 'sellaisenaan'. Kun julkisuus ei täyttänyt hallituksen luottamusta keskusta teki vaalikampanjan, jossa se oli "tuomittu onnistumaan". Tämä saa Holkerin lausumaan profeetallisen tuomion politiikan viihteellistymiselle ja mielikuvien luonnille. Holkerin mukaan "olemme tiellä, jota minä en pidä poliittisesti järkevänä."

Tiedotustutkimuksesta ei toki löydy vain yhtä näkökulmaa politiikan ja julkisuuden suhteeseen. Kärjistäen voidaan kuitenkin väittää, että sen piirissä julkisuus on usein korotettu politiikan yläpuolelle. Tämä julkisuuden korkeuksista suunnattu 'katse politiikkaan' tulee erityisen selvästi esiin ns. kulttuurisessa tiedotustutkimuksessa. Fisken ja Hartleyn mukaan sen tutkimuskohteena ovat prosessit, joissa viestinnän välittämät kulttuuriset merkitykset tiivistyvät yhtenäiseksi näkemykseksi siitä todellisuudesta, jonka kanssa olemme kasvokkain (K. Pietilä \& Sondermann 1987, 23). Etenkin althusserilaisesti tai muuten kriittisesti virittynyt kulttuurinen näkökulma osoittaa ympärillämme häärivät tajunnan muıkkaajat, massakulttuurin myyntimiehet, omaa ideologiaa totuutena kauppaavat poliitikot ja vallitsevaa ajattelutapaa vahvistavat tiedotusvälineet.

Tässä suhteessa kulttuurisella tiedotustutkimuksella on pyhä salapoliisin tehtävä yhteiskunnassa: se paljastaa manipulointia ja ideologisuutta koulukirjoistá ja uutislähetyksistä, mutta samalla se ylenkatsoo politiikkaa ja kieltäytyy ymmärtämästä 
sen tarkoitusta. Vaikka se hyväksyisikin ajatuksen politiikasta 'yhteisten asioiden hoitamisena', se nähdään aina alisteisena ideologiselle hallitsemiselle ja manipuloinnille. Julkisuus on toki kietoutunut yhteen politiikan kanssa, mutta se on 'puhtaampi osapuoli', jonka politiikka - tai oikeammin valta - tahraa.

Sama 'katse politiikkaan' välittyy myös Kauko Pietilän ja Klaus Sondermannin esittämässä tiedotustutkimuksen sosiologisessa näkökulmassa, joskin se avaa ovia myös politiikkamyönteisemmälle tulkinnalle. K. Pietilä ja Sondermann käsittelevät julkisuutta ihmisten organisoijana, joka ryhmittelee heitä suhteeseen ja yhteyteen maailman kanssa (emt., 42). Organisoinnin lähtökohtana on 'meidän' ja 'niiden' välisten ryhmien muodostaminen. 'Me' -ryhmä rakentuu viestimien ja yleisöjen välisestä liitosta, kun taas poliitikot on tuomittu aina 'niiksi'. 'Ne' voivat päästä yhteyteen ihmisten kanssa vain viestinten armosta.

Idea ihmisten organisoimisesta julkisuudessa on monilta osin hedelmällinen lähtökohta, vaikka se implikoikin politiikan ulospelaamista. Tätä kuvaa vahvistaa Kauko Pietilä artikkelissaan Julkisuus on peli eikä peili (1989), jossa hän esittää, että julkisuudessa käydään taistelua siitä, hallitsevatko sitä viestimet vai 'liitännäiset äänet' eli organisoitumiskonseptiossa mainitut 'ne'. K. Pietilä jakaa pelin vaiheet historiallisesti 1) paternalismin, 2) populismiin, 3) semiotilkkaan ja 4) 'subversiiviseen mahdollisuuteen'. Paternalistinen ja semioottinen vaihe edustavat tilannetta, jossa peliä hallitsevat 'liitännäiset' äänet.

Näistä semioottinen vaihe edustaa ainakin yhtä vallitsevaa näkemystä poliitikkojen keskuudessa. Sen mukaan politikkojen on luotava performatiivisia aloitteita, joita viestimet sitten tulkitsevat. Politikkojen asenteita kuvaa K. Pietilän lainaama Kalevi Sorsan lausunto Hufvudstadsbladetissa 5.12.1984:

"Politiikan tehtävänä olisi esittää tulkinta tapahtuvasta ja esittää tavoitteita yhteiskunnan kehitykselle (...) (J)ulkisen sanan tehtävä olisi kertoa kansalle, mitä tapahtuu todella. Tärkeätä olisi tarkistaa faktat, kertoa ne kaikki tarkoituksenmukaisesti, valikoimatta sekä erottaa arvailut, spekuloinnit ja mielipiteet selkeästi toisistaan." (K. Pietilä 1989, 42).

Pietilälle Sorsan lausunto on ainakin implisiittisesti todistus politikkojen hallitsemispyrkimyksistä ja jopa naiiviudesta. Sorsa asettaa politiikan juikisuuden yläpuolelle ja vaatii sitä toistamaan politikkojen tulkintoja muka objektiivisina faktoina.

Pietilä kokee kuitenkin politiikot tästä huolimatta varteenotettavina vastustajina, sillä politiikka pyrkii kansalaisyhteiskunnan nujertamiseen ja sen alistamiseen hirschiläisen turvavaltion komentoon. Julkisuuden tehtävänä on täliöin puolustaa kansalaisyhteiskuntaa kieltäytymällä hyväksymästä politiikan pyrkimyksiä. Tämä tapahtuu siirtymällä julkisuuden pelin semioottisesta vaiheesta 'subversiiviseen mahdollisuuteen', jolloin aloite yhteisten asioiden hoitamisessa siirty valtiolliselta politiikalta kansalaisyhteiskunnalle. Samalla viestimet ottaisivat aloitteen itselleen ja lakkaisivat tulkitsemasta ilmiöitä siitä näkökulmasta, kuka puhui hyvin ja kuka huonosti. 


\section{Julkisuuden ja poliitiikan yhteenkietominen on keino hallita asioiden monimutkaisuutta}

Politiikan tekemisen ja sen tutkimisen ongelmana on oflut se, että politïikka julkisuudessa näyttää joltakin muulta kuin 'asioiden hoitamiselta asioina'. Tämã ongelma ei ole toki ollut kiertämätön. Esimerkiksi Kyösti Pekonen (1986 ja 1991) on jäsentänyt politiikan symbolisuutta, joka astuu kuvaan silloin kun politiikkaa uhkaa rutinoituminen. Symbolien tehtävänä on vetää politiikasta vieraantuneet yksilöt takaisin hoitamaan yhteisiä asioitaan. Tämän saavuttamiseksi yhteisiin asioihin liittyä todellisuus on esitettävä jotenkin poikkeuksellisesti. Tässä rutiinin ylittämisessä on mitä konkreettisimmin kyse politikan ja julkisuuden ythteenkietoutumisesta.

Pekonen antaa aloitteen politikalle. Se hakee yhteyttä ihmisiin poikkeuksellisen esittämisen keinoin. Tämä esittäminen tapahtuu julkisuudessa ja julkisuutta silmällä pitäen. Tiedotustứkimuksessa tätä tavoitetta ei ole aina nähty tai sitä ei ole haluttu ymmärtää. Tämä on johtanut siihen, että tiedotustutkijat ovat törmänneet vaikeuksiin pyrkiessään selittämään sitä, mitkä poliittiset kysymykset nousevat julkisuuteen ja ennen kaikkea, miksi ne ovat seliaisia kuin ne ovat.

Politiikan ja julkisuuden kietoutuminen ei ole toki uusi ilmiö. Tosin voidaan väittää, että se on jatkuvasti voimistumassa. Osittain tämä on seurausta 'yhteisten asioiden' jatkuvasta monimutkaistumisesta. Faktojen, mielipiteiden ja tulkintojen moninajsuus aiheuttaa aina epäjärjestystä, joka on ainakin asioiden hoitamisen kannalta epätoivottavaa. Epäjärjestyksen poistamiseksi asiat onkin tuotava julkisuuteen, jossa niitä jäsennetään ja jonka kautta ihmisiä kiinnitetään heitä koskeviin asioihin. Politiikka on näin ollen tulkintaa ja organisointia, vaikkakin sen lopullisena tavoitteena on yhteisten asioiden hoitaminen.

Koska K. Pietilä ja Sondermann ovat jo kuvanneet, mitä politiikan ja julkisuuden yhteen kietoutuminen on kansalaisyhteiskuntaa puolustavan julkisuuden näkökulmasta, pyrin itse selvittämään, mitä se voisi merkitä politiikasta käsin katsottuna. Eli kysymys kuuluu: miten politiikka pyrkii hoitamaan monimutkaisia poliittisia kysymyksiä, ja minkä aseman julkisuus saa tässä tehtävässä? Tarkastelen tätä kysymystä ns. konstruktivistisen politiikan tulkinnan näkökulmasta. Nimitys on peräisin Murray Edelmanin (1988) politiikan näytöksen ideasta. Havainnollistan tarkastelua matkan varrella Suomen EY-jäsenyyttä koskevan keskustelun avulla.

\section{Popperilainen nākökulma: politiikka on ongelman ratkaisua}

Politiikka ymmärretään yleisesti yhteisten asioiden hoitamisena. Asioiden monimutkaistuessa asioiden hoitaminen asioina kuitenkin hämärtyy ja samalla julkisuuden merkitys politiikassa kasvaa. Tähän lähtöoletukseen voidaan politiikassa reagoida kah. della tavalla, joita Edelman (1988) on kutsunut positivistiseksi ja konstruktivistiseksi po. litiikan tulkinnaksi. Itse käytän positivistisesta jäsennystavasta nimitystä popperilainen politiikan tulkinta, mikä vähentänee vaaraa jäsennyksen väärin ymmärtämisestä. Popperilaisen politiikan tulkinnan perustana on ajatus tulevaisuuden indeterministisyydestä. Sen hyväksymisen myötä ihmiset saavuttavat rationaalisen asenteen, jonka avulla 
he voivat yrityksen ja erehdyksen kautta hallita kohtaloaan. Ihmisten kyvyt ovat kuitenkin rajalliset, joten paremman tulevaisuuden tekemisessä on edettävä vähitellen osittaisuudistusten (piecemeal engineering) tietä (Popper 1974, 223).

Vaikka Popperin reseptiä on konkreettisesti sovellettu lähinnä suunnittelussa, sillä voidaan nähdä laajempaakin merkitystä politiikassa. Yhteisten asioiden hoitoon liitettynä negatiivisen utilitarismin periaate on johtanut politiikan funktionalisoitumiseen. Sen toimintatavat ovat ideaalitapauksessa saman aikaisesti joustavan pragmaattisia ja tieteenomaisen eksakteja. Politiikalla on (tieteen tavoin) kyky löytää yhteiskunnassa vallitsevia ongelmia sekä järjestää ja analysoida niitä päätöksentekoa varten. Sillä on käytössään myös testatut menetelmät, kuten parlamentarismi ja työmarkkinajärjestelmä, joiden avulla yhteiskunnan erilaisia funktioita koskevat häiriöt voidaan poistaa.

Popperilainen politiikan tulkinta tunnustaa kuitenkin, että yhteiskuntaan liittyä epäeksaktisuus, ihmisten intressien yhteensovittamattomuus ja etenkin tulevaisuuden avoimuus aiheuttavat vaikeuksia tieteenomaiselle funktionaalisuudelle. Tästä syystä ongelman ratkaisua ohjaa deduktiivinen logiikka, jota Popper on kuvannut neliportaisella skeemalla: P1 - TT (tentative theory) — EE (error elimination) - P2 (esim. Popper 1983, 72). P1 kuvaa lähtökohtana olevaa yhteiskunnasta löydettyä ongelmaa, $\Pi$ sen korjaamiseksi esitettyä kokeilevaa teoriaa ja EE siinä havaittujen virheiden eliminointia. Niiden seurauksena syntyvä P2 on ratkaisu lähtökohtana olleeseen ongelmaan. Se ei kuitenkaan poista sitä kokonaan, sillä ratkaisu ei yleensä pysty poistamaan kaikkia ongelman elementtejä. Se saattaa sisältää myös siemenen uusiin ongelmiin, sillä kaikki yhteiskunnalliset teot kantavat mukanaan tarkoittamattomia sivuvaikutuksia.

Popperilaisessa tulkinnassa on keskeistä sen pyrkimys rajattujen yhteiskunnalisten ongelmien hallintaan. Näin ollen se tähtää faktojen löytämiseen nïn ongelman syistä kuin niiden ratkaisuistakin. Sen mukaan politikan monimutkaisuus on seurausta tiedon puutteesta ja asioiden moninaisuudesta. Ne voidaan kuitenkin kiertää käsittelemällä politiikassa vain tarpeeksi rajattuja kysymyksiä, joiden hallinta ei joudu kyseenalaiseksi. Edelmanin mukaan tämä todistaa sen, että popperilainen politiikan tulkinta näkee yhteiskunnallisen todellisuuden kokoelmana yksimerkityksisiä faktoja (Edelman 1988, 1-2). Tämä ohjaa myös politiikan ja julkisuuden suhdetta. Sitä on löydettävissä kaksi elementtiä. Ensiksikin politiikka pystyy asiantuntijoiden avustuksella usein valmistelemaan asiat päätöksentekokuntoon ilman julkisuuden sanottavaa osallistumista siihen. Toiseksi politiikalla on taipumus antaa Sorsa -lainauksen tavoin julkisuudelle tehtäväksi heijastaa todellisuutta 'sellaisenaan'. Tästä seuraa se, että julkisuudessa voidaan esittää eriäviä mielipiteitä politiikan tarjoamista toimintavaihtoehdoista, mutta sen jäsentämä kuva todellisuudesta on oltava ainakin lähestulkoon samanlainen kaikille.

Politiikan tavoittelema julkisuuden hallinta ja siinä koetut epäonnistumiset (vrt. Paasio ja Holkeri) ovat asettaneet popperilaisen tavan jäsentää politiikkaa uuteen tilanteeseen. Sen asema yhteiskunnan toimintaa johtavana periaatteena ei tosin ole uhattuna, sillä parlamentarismille, hallinnossa tehtävälle suunnittelulle ja päätöksenteon valmistelulle ei löydy korvaajaa. Sen sijaan kompleksisten kysymysten hallinta on osoittautunut ongelmalliseksi. Se ei ole johtanut niinkään politiikan ongelman ratkai- 
sun ideaalista luopumiseen vaan üudenlaisen suhteen luomiseen julkisuuteen.

Erityisen selvästi julkisuussuhteen tarkistus näkyy EY-keskustelussa, joka on noudattanut poikkeuksellisia uria. Faktojen hallinta on jäänyt ympäripyöreiden selontekojen tasolle (vrt. hallituksen EY-seionteko). Pallo on heitetty kansalaisille, joiden mielipiteillä on entistä vahvempi painoano poliitikkojen tekemille valinnoille. Tätä voitaisiin ensiksikin pitää merkkinä Pekosen esittämästä politiikan modernisoitumisesta. Toisaalta se voi myös heijastella yksinkertaisesti poliitikkojen tasapainottelua kannattajaryhmien erilaisten mielipiteiden välillä.

Kolmantena vaihtoehtona voitaisiin olettaa, että koko politiikan tekotapa eläisi murrosta. Kun pääministeri Esko Aho totesi MTV:n viestintäseminaarissa syyskuussa 1991, että "politiikka tapahtuu yhä enemmän julkisuudessa" hän tarkoitti todennäköisesti sitä, että poliitikkojen on entistä paremmin informoitava kansalaisia (itse ymmärtämistään) monimutkaisista asioista. Ahon lausunto voidaan tulkita kuitenkin myös siten, että hän suositteli asioiden tuomista 'keskeneräisinä' julkisuuteen, jonka jälkeen ne saisivat lopullisen muotonsa inmisten niille antamien merkitysten pohjalta. Tällöin julkisuudesta ei puhuttaisi enää todellisuuden heijastajana vaan politiikan paikkana, jossa monimutkaiset asiat jäsentyisivät ratkaisuvaihtoehdoiksi ja inmiset organisoituisivat niiden pohjalta.

\section{Konstruktivistinen näkökulma: politiikka on kuvien rakentamista}

Jos popperilainen tulkinta lähestyy politiikkaa kuin tiedettä, konstruktivistinen jäsennystapa näkee sen informaation, tai ehkä oikeammin, mielikuvien välityksenä. Popperilainen ja konstruktivistinen tulkinta eivät ole joka suhteessa toistensa antiteesejä, mutta ne asettuvat tiukasti vastakkain tavassa, jolla ne ymmärtävät yhteiskunnallista todellisuutta.

Kun popperilainen tulkinta perustuu todellisuuden yksimerkityksisyyteen ja sen rationaaliseen hallintaan, se etsii 'totuutta' havaintojen ja todellisuuden vastaavuudesta. Tietoteoreettisesti se edustaa näin ollen puhdasta totuuden korrespondenssiteoriaa. Konstruktivistinen tulkintatapa taas kieltää yksimerkityksiset faktat. Sen mukaan ei ole edes olemassa yhtä yhteiskunnallista todellisuutta vaan useita todellisuuksia, jotka ovat seurausta erilaisista tavoista tulkita yhteiskunnallisia ilmiöitä.

Tässä vaiheessa on syytä tehdä ero yhteiskunnallisen todellisuuden sekä luonnon ja ulkoisen maailman muodostaman todellisuuden välillä. Yhteiskunnallinen todellisuus koostuu inmisiä yhteisöjen osina koskettavista ilmiöistä, kuten työttömyydestä tai Euroopan integraatiosta. Ne ovat reaalisia ilmiöitä, vaikkei niillä olekaan fyysistä muotoa. Konkreettisuuden ja abstraktisuuden sekoittuminen antaa mahdollisuuden tulkita niitä eri tavoin esimerkiksi sen mukaan, kuinka omakohtaisiksi tai kiinnostaviksi ne koetaan ja mihin muihin yhteiskunnallisiin ilmiöihin niiden katsotaan liittyvän.

Yhden todellisuuden hajoaminen useiksi todellisuuksiksi on näin ollen seurausta eri ilmiöitä koskevien tulkintojen yhdistelemisestä ja niiden painottamisesta. Näihin prosesseihin ihmisillä on lähes täydellinen vapaus. Sen sijaan ulkoista todellisuutta he eivät pysty tulkitsemaan mielensä mukaan, ainakaan siinä mielessä, että he kieltäisivät sen olemassaolon. Esimerkiksi vesisateen yllättämä jalankulkija ei voi välttyä kastu- 
masta vain välttämällä sen havaitsemista tai 'tulkitsemalla' sadepisaroita esimerkiksi auringonsäteiksi.

Toki vesisadekin saa erilaisia merkityksiä sen mukaan, kohtaako sen ennätyskuivasta kesästä kärsinyt maanviljelijä vai rantalomaa viettävä kesälomalainen. Tästäkin huolimatta vesisade ei hajoa todellisuuksiksi, koska se edustaa konkreettista ilmiötä, jonka saama merkitys niin maanviljelijälle kuin kesälomalaisellekin on helposti ennustettavissa. Sen sijaan yhteiskunnallisissa kysymyksissä ainakin syntysyiltään abstraktin ilmiön liittäminen muihin ilmiöihin on täysin vapaata. Työttömyys voi merkityksen annossa liittyä työttömien oletettuun laiskuuteen, idänkaupan tyrehtymiseen, maan elinkeinorakenteen vääristymiseen tai vaikkapa talousjärjestelmän tuhoon.

Yhteiskunnallinen todellisuus hajoaa useiksi todellisuuksiksi etenkin silloin, kun sen sisältämät ilmiöt ovat monimutkaisia ja sisäisesti ristiriitaisia. Esimerkiksi EY-jäsenyyskysymykseen on sisäänladattuna useita konfiktin siemeniä, joiden olemassaoloa tuskin kukaan kieltää. Popperilaisessa politiikan tulkinnassa elätellään toivoa siitä, että sen avulla voitaisiin löytää ratkaisu, jossa hyödyt olisivat mahdollisimman suuret ja haitat mahdollisimman pienet. Ongelmana on tällöin se, pystyykö politiikka hallitsemaan kaikki EY-jäsenyysasiaan liittyvät faktat vai törmääkö se vajavaisen rationaalisuuden asettamiin rajoihin.

Riippumatta siitä, kuinka riittäväksi politiikan hallintakyky lopulta muodostuu, popperilainen tulkinta unohtaa todellisuuden hajoamisen mahdollisuuden. Mitä tapahtuu, jos kaikki kansalaiset eivät tulkitsekaan 'selviä faktoja' samalla tavoin? Seurauksena on politiikan kriisi, joka heijastuu päättämättömyytenä tai kansan jakautumisena valitun ratkaisun seurauksena. Kumpikaan vaihtoehto ei ole politiikalle erityisen mairitteleva. Kansan jakautumisella pelottelu voi tuntua kaukaa haetulta, koska sille ei juuri löydy historiasta vahvistusta. EY-jäsenyyden tapaisissa suurissa kysymyksissä tämä mahdollisuus on kuitenkin entistä reaalisempi. Se että jakautumista tuskin tapahtuu, on suurelta osin seurausta politiikan kyvystä varautua jakautumisuhkaan.

Konstruktivistinen ajattelu pitää tulkintojen moninaisuutta etenkin kompleksisissa poliittisissa kysymyksissä paitsi väistämättömänä myös toivottavana. IImiöille annettujen merkitysten erilaisuus ja syntyneen merkityskonfliktin ratkaiseminen muodostavatkin itse asiassa politikan ytimen. Politiikan lähtökohtana on siis tilanne, jossa yhteiskunnallisesta ilmiöstä vallitsee lukuisia tulkintoja. Politijkan tehtävänä on järjestää 'monimutkaista ja hämmentävää maailmaa' (Edelman 1971, 65-66) koskevat havainnot jotenkin ymmärrettäväksi merkityspaketiksi.

Tässä vaiheessa yksilöllinen tulkinta yhteiskunnallisesta tilanteesta pyritään tekemään yhteiseksi. Noustakseen yhteiseksi asiaksi tulkinnan on konkretisoitava ihmisiä koskevat uhkat ja toivekuvat. Esimerkiksi EY-kysymyksessä näytösten rakentajilla on tähän kaksinkertainen vapaus. Tulkinnat eivät ole vastuussa sen enempää tulevaisuuden seurauksista kuin EY:n vaikutusten määritelmistäkään. Mitä konkreettisempi tulkinta on, sitä varmemmin se muuttuu 'yhteiseksi kysymykseksi', joka sitoo ihmisiä tarjoamaansa ratkaisuun.

Konstruktivistisen tulkinnan mukaan julkisuus on politiikan paikka, jonne näytöksiksi rakennetut tulkinnat yhteiskunnallisista tilanteista viedään. Tiedotusvälineet ja 
kansalaiset tulkitsevat niitä edelleen, ottavat joidenkin näytösten esittämät kysymykset 'yhteisiksi asioiksi' ja hylkäävät osan näytöksistä. Hyväksyminen ei rajoitu pelkästään näytöksen sisältämän ratkaisun tukemiseen, vaan myös sen vastustaminen merkitsee sen sisältämän kysymyksen nousemista yhteiseksi. Näin ollen vain näytöksestä vaikeneminen merkitsee politiikan täydellistä epäonnistumista.

\section{Politiikan nāytös ongelman, ratkaisun, vihollisen ja historian rakentamisena}

Monimutkaista ja tulkinnanvaraista yhteiskunnallista tilannetta jäsentävän merkityspaketin nouseminen poliittiseksi kysymykseksi on riippuvainen siitä, kuinka hyvin se pystyy konkretisoimaan inmisiä koskevat uhkat ja toivekuvat. Tämä edellyttää ensiksikin sitä, eltä kansaiaiset kokevat näytösten esittämän asian yhteiseksi, eli he organisoituvat joko sen puolustajiksi tai vastustajiksi. Esimerkiksi EY-kysymyksessä sekä MTK:lainen maanviljelijä ja teollisuusyrittäjä kokevat asian heille itselleen tärkeäksi. Tärkeys ei ole riippuvainen siitä, esittääkö asian oman leirin edustaja vai vastustaja. Talonpojan asenne EY-jäsenyyttä vastaan voi vahvistua jopa enemmän Metalliliiton puheenjohtajan Per-Erik Lundhin kuin Heikki Haaviston puheenvuoron seurauksena.

Näytökseksi puetun merkityspaketin on panostettava toiseksi uskottavuuteen ja vakuuttavuuteen. Sen on sisällettävä juoni, joka estää kilpailevien juonien hyväksymisen saman aikaisesti. Sen on myös liityttävä edeltäjiinsä - esimerkiksi EY-kysymyksessä Eta-tavoitteisiin taj maatalouden eloonjäämistaisteluun siten, että ihmiset voivat liittää uuden juonimuutoksen aikaisempiin käsitysmaailmoihinsa. Lisäksi näytöksen juonessa on oltava liittymäkohtia yleisiin arvoihin ja uskomuksiin, joiden avulla näytös tulee legitiimiksi. (Bennett \& Edelman 1985, 163).

Ymmärrettäyyttä ja uskottavuutta voidaan pitää näytöksen onnistumisen yleisinä ehtoina. Ne eivät kuitenkaan vielä kerro mitään oleellista siitä, miten näytös iuo omat ehdotuksensa merkitysten kiistanalaisuuden ratkaisemiseksi. Näytöksen toimimi. nen edelyttääkin sen saattamista liikkeelle kertomuksen tavoin. Edelman erottaa politiikan näytöksestä kuusi elementtiä. Ne ovat 1) ratkaisu, 2) ongelma, 3) johtajan mää. rittely, 4) vastustajan kuvan konstruoiminen, 5) historian rakentaminen ja 6) itsemäärit. tely (Edelman 1988).

Näytösten rakentaminen ja niiden murtautuminen politiikan ja julkisuuden päiväjärjestykseen noudattaa tietynlaista dialektiikkaa. Näytöksen esittämän ongelman kokeminen yhteiseksi ja siihen tarjotun ratkaisun hyväksyminen edellyttää yleensä ainakin yhtä vastanäytöstä. Siinä tilanne nähdään perustavan laatuisesti eri tavoin, jolloin sen esittämä ratkaisukin asettuu poikkiteloin vastustajan esittämän ratkaisun kanssa.

Esimerkiksi EY:n vastustajat keskittyivät tilanteen määrittelyissään pelkästään jäsenhakemusaloitteen hylkäämiseen sen sijaan, että ne olisivat muotoilleet uusia toimintavaihtoehtoja sen rinnalle. Näin ollen näytösten ja niiden vastanäytösten ongelman ja ratkaisun määrittelyille muodostuu yhteinen kosketuspinta. Samalla monimutkainenkin poliittinen kysymys polarisoituu julkisuudessa joko-tai -akselille. Esimerkiksi Suomen asema Euroopan integraatiossa kiteytyi kysymykseen, haemmeko EY:njäsenyyttä vai emme. Presidentti Mauno Koiviston maalaamat kuvat Suomea vääjäämättömästi koskevista muutoksista (Helsingin Sanomat 8.2.1992) rakensivat 
juonta, jossa jäsenyyden hakeminen nähtiin ainoana järkevänä vaihtoehtona.

\section{Politiikka etenee ratkaisusta ongelmaan}

Popperilaisessa politikan tulkinnassa ongelma ja ratkaisu muodostavat jatkuvasti vuorottelevan parivaljakon. Ongelmalle etsitään ratkaisu, joka poistaa sitä osan, jonka jälkeen uusi ongelma vaatii jälleen uutta ratkaisua. Rationaalisuuden ainoana esteenä on tulevaisuuden avoimuus, eli tekojen kaikkia seurauksia ei voida nähdä etukäteen. Monimutkaisissa kysymyksissä tulevaisuuden avoimuuden rinnalle tulee myös toinen avoin alue: on mahdotonta nähdä edes mistä kaikesta sen yhteydessä on kysymys, jolloin myös se, mikä sen yhteydessä nähdään ongelmaksi on suhteellista. Konstruktivistisessa tulkinnassa tämä johtaa ongelman ja ratkaisun välisen lineaarisen liikkeen pysäyttämiseen. Ongelmat, ratkaisut ja päämäärät sekoittuvat keskenään.

Esimerkiksi suhtautumisessa ydinvoimaan voimayhtiöt ja teollisuus voivat käyttää tulevaisuuden ennakoitua energiapulaa ongelmana, johon on vastattava rakentamalla lisää ydinvoimaloita. Ydinvoiman vastustajat taas voivat nähdä ongelmana ydinvoimalarakentamisen seurauksena muodostuvan energiaparatiisin, joka johtaa energian tuhlauksen tielle (Osmo Soininvaara Helsingin Sanomissa 4.1.1992). On selvää, että ydinvoima on ollut potentiaalisena ratkaisuna olemassa ennen kumpaakin perustelua.

Jotta näytös kohoaisi politiikan päiväjärjestykseen, sen esittämän ongelman tulisi viestiä todellisesta uhkasta. Mitä vakuuttavampi kuva kriisistä, sitä varmemmin näytös koetaan yhteiseksi asiaksi. Ongelman hehkuttaminen sisältää kuitenkin paradoksin: samalla kun kriisi sitoo ihmisiä näytökseen, se agitoi heitä politikan vastaisuuteen. Politiikan tavoitteenahan on edesauttaa yhteiskunnan säilymistä ja legitimiteettiä. Tämä tapahtuu suurelta osin siten, että politiikka hallitsee inmisten välisiä ristiriitoja sekä heitä koskevia ongelmia. Jos politiikka rakentaa ongelmista kriisejä, se lisää yhteiskunnan epävakaisuutta (tai ainakin käsitystä siitä). Näin ollen se antaa kansalaisille aiheen epäillä, että se on epäonnistunut tehtävässään. Tämä merkitsee sitä, että politijkan on tasapainoteltava konsensuksen ja ristiriitojen hallittujen ilmaisujen välillä.

\section{Johtajan määritteleminen}

Johtajan osuus politikassa ja sen julkisuuskuvassa on yleensä tunnustettu symboliseksi. Toisin sancen osapuoiesta riippumatta on hyväksytty se seikka, että poliittinen johtaja edustaa jotain enemmän ja jotain muuta kuin mitä hänen tekonsa 'faktuaalisesti' ovat. Politiikan näytöksen kannalta johtajaelementissä on olennaista se, että johtaja toimii samanaikaisesti sekä näytöksen 'merkittynä' että 'merkitsijänä'. Poliittiset toimijat rakentavat yhteyttä tulkitsemiensa ratkaisun ja ongelman välille ja antavat niille omia merkityksiään. Sen jälkeen kun heidän esittämänsä asia nousee yhteiseksi, he itse edustavat sitä. Näin kansanedustaja Martti Turista tulee Herra Ydinvoima ja Heikki Haavistosta Herra Maaseutu \& Itsenäisyys.

Johtajuus politikassa ei viittaa välttämättä vain poliitikkoihin, vaan myös asiantuntjat voivat kohota johtajiksi. Rajan vetäminen sen välilie, muodostaako asiantuntijan 
merkityspaketti vai politiikon reagointi siihen näytöksen, jää usein tulkinnanvaraiseksi. Asiantuntijoiden voidaan joka tapauksessa katsoa tuottavan raaka-aineita näytösten rakentamiselle, he esittävät asiaa koskevat faktat ja niiden tulkinnat politikoille.

Politiikassa on siis usein kysymys asiantuntijoiden tulkintojen tulkinnoista.

\section{Vastustajan rakentaminen, itsemäärittely ja historian kuvaus}

Sekä popperilaisessa että konstruktivistisessa tuikinnassa ristiriidat nähdään politiikassa väistämättöminä ja jopa välttämättöminä. Popperilaisessa jäsennyksessä ristiriitojen ilmeneminen on demokraattisuuden edellytys. Kansan tahto ja arvot välittyvät vaaleissa. Politiikan tehtävänä on toimia kansan mandaatilla ja jakaa arvoja kansalaisten tahdon mukaisesti. Konstruktivistisessa tulkinnassa taas ristiridat littyvät asioiden rakentamiseen yhteisiksi. Tämä rakentaminen tapahtuu politiikan näytöksissä, joissa vakuutetaan ongelmien vakavuutta ja ratkaisun välttämättömyyttä. Tämä edellyttää myös viholliskuivan liittämistä näytökseen. Vihollisella on kaksiulotteinen tehtävä. Se antaa 'historiallisen selityksen' ongeimalle, jonka ratkaisemiseen näytös pyrkii. Toiseksi se toimii erottajana 'meidän' ja 'niiden' välillä. Eli kaikki ne ominaisuudet, jotka erottavat ihmisiä vihollisesta, työntävät heitä näytöksen kannattajien leirin.

EY-keskustelussa vihollisen rakentaminen on ollut varsin vähäistä. Tosin myös 'viileä' analyysi voi olla viholliskuvan pönkittämistä. Esimerkiksi Simopekka Nortamo (Helsingin Sanomat 14.1.1992) jaotteli EY:n kannattajat ja vastustajat objektiivisesti etuja ja haittoja jäsentäviin sekä dogmaattisiin ja populistisiin piireihin. Viholliseksi tulkjtut dogmaatikot pelottelevat vennamolaisin äänenpainoin itsenäisyyden menettämisestä. Näin ollen Nortamon näytös jakaa inmisiä paitsi EY-asenteen perusteella, myös sillä, pitävätkö he itseään yleensä dogmaatikkoina, fundamentalisteina tai Paasikivestä ja Kekkosesta kiinni pitävinä menneisyyden miehinä. Tällä tavoin Nortamo ikään kuin vetää kysymyksen hämmentämiä 'kunnon ihmisiä' vääräoppisten leiristä oikealle puolelle.

Nortamon omat perustelut ovat kiinnostavia. Hänen tunnepohjaisuutta vastaan nostamiaan kriteerejä ovat esimerkiksi uhka länsimaisen identiteetin ulkopuolelle jäämisestä sekä taloudellisesta ja poliittisesta masennuksesta, lievästi populistisia mielikuvia nekin.

\section{Popperilaisuus ja konstruktivismi nojaavat rationaalisuuteen}

Popperilaisen ja konstruktivistisen politiikan tuikinnan asettaminen vastakkain (ja konstruktivistisuuden preferoiminen) implikoi sitä, että politiikan perustaminen rationaa. lisuudelie olisi jotenkin epätoivottavaa. Tämä on kuitenkin väärä johtopäätös, sillä niillă molemmilla on selvä rationaalinen pohja. Popperilaisessa tulkinnassa rationaalisuuden rajat pakottavat politijkan omaksumaan osittaisuudistusten tien. 'Yhteisten asioiden' hoitaminen etenee ongeiman ratkaisun kautta hitaasti mutta varmasti. Yhteisten asioiden monimutkaistuminen asettaa kuitenkin esteitä niiden pilkkomiselle ja hallitsemiselle. Osittaisuudistusten tien päässä ei häämötäkään rationaalisuudeń rautahäkki vaan monimutkaisuuden synnyttämä kaaos. Sen selvittäminen puhtaasti Popperin on. 
gelman ratkaisuskeeman avulla on useissa tilanteissa mahdotonta.

Toisena popperilaisen tulkinnan ongelmana on suhde julkisuuteen ja sitä kautta kansalaisiin. Kuinka vastata tilanteeseen, jossa politikan tekijöillä, tiedotusvälineillä ja yleisöllä on sovittamattomia erimielisyyksiä asioiden tulkinnoista? Julkisuuden ohjailuyritykset ovat osoittautuneet yleensä tehottomiksi. Epäonnistumisen palkaksi politikkoon on kiinnitetty lisäksi tiukkaan liimautuva tyhmän ja yksinkertaisen maine.

Konstruktivistisessa tulkinnassa rationaalisuus merkitsee monimutkaisten kysymysten - ja nimenomaan niiden relativistisuuden ymmärtämistä. Senkin tavoitteena on popperilaisen jäsennystavan tavoin 'yhteisten asioiden' ratkaiseminen. Tavoitteen saavuttamiseksi politïikan on ensiksi tehtävä asiat yhteisiksi. Politiikan näytösten tuominen julkisuuteen johtaa yleensä monimutkaisen kysymyksen kiteytymiseen kahteen vastakkaiseen vaihtoehtoon, jota politiikka jälleen tulkitsee päätöksentekoa varten.

Politiikan ja julkisuuden yhteenkietoutuminen tuo politiikan kannalta 'yhteisten asioiden' hoitamiseen myös epävarmuuden elementin. Politïkka ei voi määrätä, mitkä asiat nousevat yhteisiksi tai millaisia tulkintoja ne saavat. Tässä suhteessa julkisuus on Kauko Pietilän antamassa merkityksessä peli, jossa viestimet ja niiden kohteet taistelevat johtoasemasta. Politiikassa tämä vaihe jää usein kokonaan huomiotta, sillä se joutuu 'näkyvän politiikan', eli varsinaisen päätöksenteon yliajamaksi. Syntyy harhakuva siitä, että politiikka olisi vain päätöksentekoa, mitä se ei suinkaan ole etenkään monimutkaisissa polittisissa ratkaisuissa.

Päätöksenteko on toki politiikan näkyvin päämäärä, myös EY-jäsenhakemusta koskeva keskustelu tähtää ratkaisuun. Politiikan ymmärtämisen kannalta on olennaista kuitenkin se, että päätöksentekoa ei nähdä politiikan päätepisteenä. Päätöstä seuraavat vaiheet tarjoavatkin politiikalle eräänlaisen option toiminnalleen julkisuudessa. Edellä on tullut jo selväksi, että se pyrkii yhtäältä ratkaisemaan kulloinkin ongelmiksi koetut yhteiskunnalliset epäkohdat ja toisaalta sitomaan ihmiset heitä kaikkia koskeviin 'yhteisiin asioihin'.

Ihmisten organisoimisesta poliittisen kysymyksen pohjalle seuraa kuitenkin myös heidän jakautumisensa. Erityisen voimakkaana tämä jakautuminen näkyy EY-kysymyksessä, jossa maakuntakokouksissa huolestuneet maanviljelijät kyselevät "lähetetäänkö Brysselistä rasvattu köysi ilmaiseksi" (Helsingin Sanomat 14.1.1992). Politiikan kolmantena tehtävänä onkin estää tällaisen kahtiajaon säilyminen. Yhteisen asian synnyttämän jakaantumisen purkaminen muodostaakin politiikan prosessin toisen vaiheen.

Päätöksentekoon yltänyt politiikan prosessi pitää ikään kuin sulkea ja avata uudelleen 'jonakin muuna'. Kun Suomi on päättänyt hakea Euroopan yhteisön jäsenyyttä, myös EY:n vastustajat on saatava hyväksymään tehty ratkaisu. Samalla heidän virinnyt poliittinen aktiivisuutensa tulee kanavoida muuttuneeseen tilanteeseen. Esimerkiksi EY-kysymyksessä huomion keskipisteenä ollut keskustan johto on jo hyvissä ajoin tuonut EY-kysymyksen kyllä_ei -vaihtoehtojen rinnalle kolmannen tien. 'Kyllä, mutta -linjalla' EY:n vastustajia houkuteltiin paitsi hakemuspäätöksen taakse myös osallistumaan sen jälkeen aloitettaviin neuvotteluihin omine ehtoineen. Tämä edellyttää sitä, että uudessa tilanteessa EY-jäsenyys tuikitaan joksikin muuksi. Siitā voi tulla 
jopa Suomen maatalouden selviytymisen väline, jonka avuila maanviljelijät hankkivat ymmärtãmystä 'vihollistensa' joukossa ja vāistāvät näin EY:n halvan ruoan vyöryn.

Politiikan onnistuminen prosessin uudelleen avaamisessa edellyttää jälleen näytösten rakentamista. Tehty ratkaisu muodostaa pohjan uuden ongelman konstruoinnille, se toimii myös historian rakentamisen peruskivenā. Jos ratkaisu koetaan 'oikeaksi', siitä konstruoidaan alku menestystarinalle, joka vaatii meitā jatkamaan samalla tiellä. Jos taas ratkaisu tulkitaan virheeksi, siihen meidät johdattaneet politikot ja asiantuntjat palvelevat viholliskuvan rakentamista ja tyystin toisenlaista ratkaisua.

Vaikka politiikka näytöksineen tarvitseekin julkisuutta, sillä on hallussaan tärkeä etulyönti. Politiikan näytökset hallitsevat suurelta osin tiedotusvälineiden ja yleisön tuikintoja yhteiskunnallisista tilanteista. Ne ovat tahtoen tai tahtomattaan riippuvaisia politiikan julkisuuteen tarjoamista syötteistä. Politiikalla on myös ei-julkinen puolensa. Siitä huolimatta, että julkisuus nähtäisiin politiikan paikkana, suuri osa päätöksistä ja niihin johtaneesta valmistelusta tehdään kompleksisissakin tilanteissa 'kabineteissa' julkisuudelta salassa.

\section{Kirjallisuus}

ALANEN, Pellervo. Sosialisti Vesa on viljelijöiden EY-messias. Helsingin Sanomat 14.1.1992.

BENNET, W. Lance \& EDELMAN, Murray. Homo Narrans. Toward a New Political Narrative. Journal of Communication (1985):4.

EDELMAN, Murray. Politics as Symbolic Action. Mass Arousal and Quiscence. Chicago, Markham Publishing Company, 1971.

EDELMAN, Murray. Constructing the Political Spectacle. Chicago, The Chicago University Press, 1988.

HEMANUS, Pertti \& TERVONEN, llkka. Totuuksista utopioihin. Keuruu, Otava, 1986.

KOIVISTO, Mauno. Ma käytämme valinnanvaramme parhaiten hakemalla EY:n jäsenyyttä. Puhe valtiopäivien avajaisissa 7.2.1992. Helsingin Sanomat 8.2.1992.

KUiKKA, Jukka. "Hallitus oli oikeassa, mutta liian aikaisin". Hami Holkerin haastattelu, Uusi Suomi 29.4.1991.

NORTAMO, Simopekka. Kansalaismielipide - 3. Kolumni Helsingin Sanomissa 14.1.1992.

PEKONEN, Kyösti. Imagon merkitys modernissa politiikassa. Teoksessa: NOUSIAINEN \& WIBERG (toim.). Kansalaiset ja politiikka 1980-luvun Suomessa. Tunun yliopiston julkaisuja Sarja C 57. 1986.

PEKONEN, Kyösti. Symbolinen modemissa politikassa. Jyväskylän yliopisto, nykykulttuurin tutkimusyksikkö 25. 1991.

PIETILÄ, Kauko. Julkisuus on peli eikä peili. Politiikka (1989):1.

PIETILÄ, Kauko \& SONDERMANN, Klaus. Luonnoksia joukkoviestinnän sosiologisen tutkimuksen metodeiksi. Tampereen yliopisto, yhteiskuntatieteiden tutkimuslaitos Saja B/50. 1987.

PIETILÄ, Veikko. Tiedotustutkimus teitä ja tienvittoja Tampereen yliopisto tiedotusopin laitos, opetusmoniste. 1982.

POPPER, Karl. Avoin ytteiskunta ja sen viholliset. Otava, Keuruu, 1974.

POPPER, Kart. Knowledge: Subjective versus Objective. Teoksessa: MILLER, David (ed.). A Pocket Popper. Glasgow, Fontana Press, 1983.

WIBERG, Matti. Politiiikan agendat. Erittelyjä politiikan päiväjärjestyksen muotoutumisen ehdoista. Tiedotustutkimus (1989):2. 